\title{
SUGARCANE MOLASSE AND WHEY AS ADDITIVES IN THE SILAGE OF LEMONGRASS (Cymbopogon citratus [DC.] Stapf) LEAVES
}

\author{
Lucía María Cristina Ventura-Canseco ${ }^{1}$, José Alfredo Mendoza Nuñez ${ }^{1}$, Miguel Abud-Archila ${ }^{1}$, \\ María Ángela Oliva-Llaven², Luc Dendooven ${ }^{3}$, and Federico A. Gutiérrez-Miceli ${ }^{1 *}$
}

\begin{abstract}
After extraction of essential oil from lemongrass (Cymbopogon citratus [DC.] Stapf) leaves by steam distillation (heat treatment), large amounts of organic wastes are obtained. This by-product could easily be used as animal feed. The potential of sugarcane molasse and whey as additives to ensile lemongrass leaves was investigated. The vegetative material was obtained after essential oils were extracted from lemongrass leaves with steam distillation. Lemongrass leaves were chopped, mixed with sugarcane molasse and whey, placed in cylindrical plastic containers, hermetically closed. The experimental design for $\mathrm{pH}$ optimization was a response surface 3-level factorial design $3^{2}$ with three replicates. Sugarcane molasse at 5,10 and $15 \%(\mathrm{w} / \mathrm{w})$ and whey at 20,25 and 30\% (w/w) were used. The $\mathrm{pH}$ of the silage decreased significantly in each treatment, but it was faster when sugarcane molasse was added. The lactic acid concentration was $2.8 \mathrm{~g} \mathrm{~kg}^{-1} \mathrm{DM}$ in silage amended with $15 \%$ molasse plus $25 \%$ whey and was higher than in silage supplemented with commercial additive after 15 d. In conclusion, it was shown that lemongrass leaves obtained as by product after extracting essential oils can be effectively ensiled with whey and sugarcane molasse as additives inducing a faster production of lactic acid.
\end{abstract}

Key words: Silage quality, response surface methodology, $\mathrm{pH}$, lactic acid.

$\mathrm{E}$ nsiling plants often gives silage suitable for feeding (Weinberg and Muck, 1996). Watersoluble carbohydrates (WSC) are fermented to lactic acid by lactic acid bacteria (LAB), which decreases $\mathrm{pH}$, inhibits the activity of plant enzymes and reduces pathogenic or spoilage bacteria that can decrease the nutritive value of the silage (Davies et al., 2000). The main objective to apply additives for ensiling is to reduce $\mathrm{pH}$ more rapidly so as to preserve carbohydrates and proteins and inhibit the growth of microorganisms that might deteriorate the silage (Zhang et al., 2000). Silage additives can be divided into two major groups: fermentation inhibitors (e.g. organic acids) and fermentation stimulators (e.g. strains of lactobacilli or readily degradable sugars) (Hetta et al., 2003). The cost and availability of commercial silage additives are often a limiting factor and by-products can then serve as an

\footnotetext{
${ }^{1}$ Instituto Tecnológico de Tuxtla Gutiérrez, Carretera Panamericana km 1080, Tuxtla Gutiérrez, Chiapas CP 29050, A.P. 599, México. *Corresponding author (biotecveg@hotmail.com).

${ }^{2}$ Universidad Autónoma de Chiapas, Facultad de Medicina Veterinaria y Zootecnia, Rancho San Francisco km 8 Tuxtla Gutiérrez Chiapas, México (biotecveg@yahoo.com.mx).

${ }^{3}$ Centro de Investigación y de Estudios Avanzados del Instituto Politécnico Nacional (CINVESTAV), C.P. 07360, México D.F., México (dendoove@cinvestav.mx).

Received: 16 May 2011.

Accepted: 23 November 2011.
}

alternative. Use of by-products depends on availability and their possible nutrimental value for cattle. In developed countries, the main treatment for silage is primarily sugarcane molasse, a by-product in sugar production (Kahi and Rewe, 2008). It has been used as a supplement for cattle manure silage (MartínezAvalos et al., 1998). Sugarcane molasse also have been used as a supplement for groundnut (Arachis hypogaea L.), sweet potato (Ipomoea batatas [L.] Lam.) and Jerusalem artichoke tops (Helianthus tuberosus L.) silages (Kaya and Caliskan, 2010).

Whey is a cheap residue of cheese production and it has been added to wheat straw and rice bran silage (Daniels et al., 1983). A combination of molasse and dehydrated whey has been used as supplements to ensile fish by-products (De Lurdes et al., 1998) and as additives for the ensiling of maize (Bautista-Trujillo et al., 2009), but it is important to find the optimal concentration for each of them. Response surface methodology (RSM) is a set of mathematical and statistical techniques used widely to determine the effects of the studied variables and to optimize different biotechnological process (Cao et al., 2008).

Lemongras (Cymbopogon citratus [DC.] Stapf) are cultivated in Chiapas and extracted for their essential oils. The extracted plant material is nutrient rich, but little is known about its potential to ensile. The objective of the present work was to optimize cane molasse and whey 
as silage additives to lemongrass leaves applying the response surface methodology.

\section{MATERIALS AND METHODS}

Lemongrass leaves were provided by 'Unión de Pequeños Productores de las Zonas Marginadas del Sureste de Chiapas S.P.R de R.I.' and harvested at Cintalapa (16 ${ }^{\circ} 40^{\prime}$ N 934' W), Chiapas, México. The vegetative material was obtained after essential oils were extracted from lemongrass leaves with steam distillation at $120{ }^{\circ} \mathrm{C}$ for $90 \mathrm{~min}$.

\section{Optimization of sugarcane molasse and whey as silage additives to lemongrass leaves}

The experimental design for $\mathrm{pH}$ optimization was a response surface 3 -level factorial design $3^{2}$ with three replicates. Sugarcane molasse at 5, 10 and $15 \%(\mathrm{w} / \mathrm{w})$ and whey at 20,25 and 30\% (w/w) were used (Table 1). From each mixture, $1 \mathrm{~kg}$ was placed in a cylindrical plastic container $(15 \mathrm{~cm}$ height $\times 12 \mathrm{~cm}$ diameter $)$ and closed airtight with a plastic lid, i.e. mini silos. Each mini silo was an experimental unit and applied in triplicate. Mini silos were kept at $30{ }^{\circ} \mathrm{C}$ for $15 \mathrm{~d}$. A $10 \mathrm{~g}$ sub-sample was taken after 0, 3, 7 and $15 \mathrm{~d}$, weighted and characterized (Megías et al., 1999).

\section{Chemical analysis}

Samples of pre- and post-ensiled mixtures were analyzed for $\mathrm{pH}$ and dry matter, organic matter, total $\mathrm{N}$ and ash content (AOAC, 1980). The neutral detergent fiber content was analyzed as described by Goering and Van Soest (1970). Lactic acid was determined colorimetrically using standard solutions $\left(0-30 \mu \mathrm{g} \mathrm{mL}^{-1}\right.$ in 5- $\mu \mathrm{g}$ increments) (Taylor, 1996). Briefly, $1 \mathrm{~mL}$ standard solution was added to $10 \mathrm{~mL}$ borosilicate tubes containing $6 \mathrm{~mL}$ concentrated $\mathrm{H}_{2} \mathrm{SO}_{4}$ and mixed on a vortex mixer. The mixed solutions were incubated in a water bath at $95-100{ }^{\circ} \mathrm{C}$ for $10 \mathrm{~min}$. The tubes were cooled to room temperature, added with $100 \mu \mathrm{L} \mathrm{CuSO}_{4}$ and $200 \mu \mathrm{L}$ para-phenyl phenol reagent and mixed on a vortex mixer. The tubes were kept at room temperature $\left(>20{ }^{\circ} \mathrm{C}\right.$ ) for $30 \mathrm{~min}$ and the absorbance measured at $570 \mathrm{~nm}$ (Madrid et al., 1999). All analyses were done five times.

Table 1. Experimental design to investigate the effect of sugarcane molasse and whey as additives in the silage of lemongrass leaves (Cymbopogon citratus) by-product and $\mathrm{pH}$ determined after $5 \mathrm{~d}$.

\begin{tabular}{lccc}
\hline Treatment & Whey & $\begin{array}{c}\text { Sugarcane } \\
\text { molasse }\end{array}$ & $\mathrm{pH}$ after 5 d \\
\cline { 2 - 3 } 1 & 20 & 5 & $5.7 \pm 15$ \\
2 & 20 & 10 & $5.1 \pm 14$ \\
3 & 20 & 15 & $4.7 \pm 0.5$ \\
4 & 25 & 5 & $5.5 \pm 23$ \\
5 & 25 & 10 & $5.0 \pm 20$ \\
6 & 25 & 15 & $4.6 \pm 0.5$ \\
7 & 30 & 5 & $5.4 \pm 0.8$ \\
8 & 30 & 10 & $4.9 \pm 14$ \\
9 & 30 & 15 & $4.6 \pm 20$ \\
\hline
\end{tabular}

\section{Determination of silage quality}

After $15 \mathrm{~d}$, the fermentation was terminated, the mini silos opened and the silage characterized. The measured characteristics were color, taste, structure, and $\mathrm{pH}$. Subsamples from different points and depths were taken, pooled and the water content determined by oven drying at $65^{\circ} \mathrm{C}$ until a constant weight was achieved. The samples were hammer-milled and characterized chemically. The $\mathrm{pH}$ was measured by heating a $100 \mathrm{~g}$ subsample in a beaker containing $100 \mathrm{~mL}$ distilled water at $60{ }^{\circ} \mathrm{C}$ for $5 \mathrm{~min}$. The supernatant was decanted, cooled at room temperature and the $\mathrm{pH}$ measured. Color was determined using color charts. The taste of the silage, which was defined as being nice, pleasant or fruity, was determined as described by Babayemi (2009). Briefly, a panel of seven people was trained to use their tongue to detect a taste by comparing it with known ones. A variety of taste-like substances, such as wine, vinegar, fruits, were provided for comparison. The structure of the silage was also determined and was found to be separable or firm.

\section{Comparison with a commercial product}

Once the optimal concentrations of sugarcane molasse and whey for ensilage were determined, lemongrass leaves were ensiled under these conditions and compared with lemongrass leaves ensiled with a commercial product Pro B\&W® (B\&W Feeds (Mobile) Ltd. Bussey Stool Farm Tarrant Gunville Blandford, England), i.e. wettable powder for silage, which contains bacteria, such as Lactobacillus plantarum, Pediococcus acidilactici, Bacillus and Lactobacillus casei, and enzymes, such as amylase, beta-gluconase, and hemicellulase. Lactic acid production and $\mathrm{pH}$ were determined after $0,3,5,7,15 \mathrm{~d}$.

\section{Statistical analysis}

All results were subjected to a one-way ANOVA to test for significant differences between treatments using PROC GLM (SAS statistical package) with the Tukey's Student Range test $(\mathrm{P}<0.05)$ (SAS Institute, 1989).

In the optimization process, all data were analyzed by multiple regressions with the least square method:

$$
Y=\beta_{0}+\beta_{1} S M+\beta_{2} W+\beta_{3} S M * W+\beta_{4} S M^{2}+\beta_{5} W^{2}
$$

where $\beta$ are coefficients to identify, SC is sugarcane molasse $(\%)$ and $\mathrm{W}$ is whey $(\%)$. The $\mathrm{R}^{2}$ were calculated for equation.

\section{RESULTS AND DISCUSSION}

\section{Optimization of sugarcane molasse and whey as silage additives to lemongrass leaves}

The concentration of sugarcane molasse (SM) and whey and the interaction between the two factors significantly affected the $\mathrm{pH}$ in silage of lemongrass leaves. Both sugarcane molasse and whey individually induced a 
decrease in $\mathrm{pH}$ while the interaction between them increased it (Figure 1a). The effect of SM on the $\mathrm{pH}$ decrease was more accentuated than that of whey (Figure 1b). The response surface curve indicated that a lower $\mathrm{pH}$ was obtained using 13-15\% sugarcane molasses combined with any of the whey concentration used (Figure 1c). A maximum $\mathrm{pH}$ decrease was obtained with $25 \%$ whey and $15 \% \mathrm{SM}$.

After lineal regression Equation [1] could be written as:

$$
\begin{gathered}
Y=8.36-0.21 S M-0.13 W+0.003 S M * W+ \\
0.002 S M^{2}+0.001 W^{2}
\end{gathered}
$$

with a $\mathrm{R}^{2}$ of $90 \%$. p-Values indicate that only $\mathrm{SM}$ and $\mathrm{W}$ factors of the model were significant $(\mathrm{p}<0.05)$. The model could be written as:

$$
Y=6.36-0.09 S M-0.16 \mathrm{~W}
$$

with a $\mathrm{R}^{2}$ of $87.27 \%$.

Minimal values for $\mathrm{pH}$ after ensiling were used to optimize the ensiling process. A minimum $\mathrm{pH}$ of 4.54 was thus obtained using $25 \%$ of whey and $15 \%$ of SM.
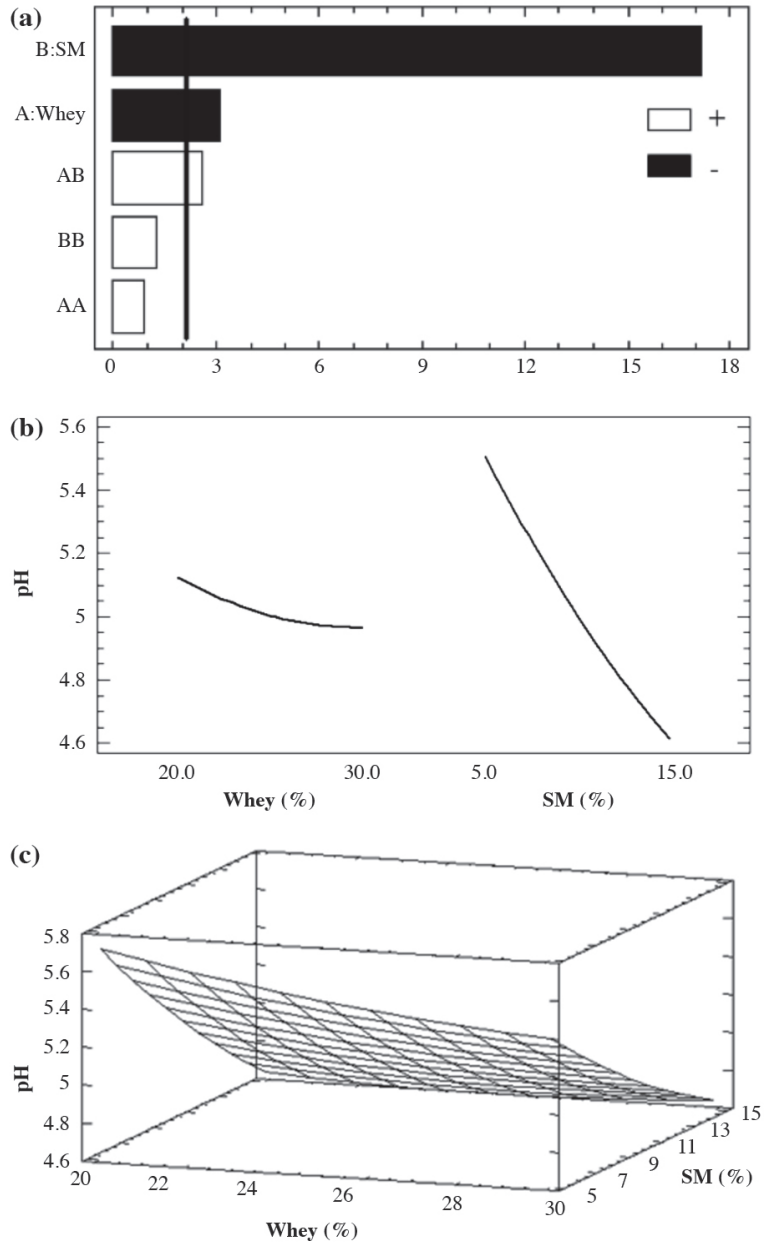

Figure 1. Standardized Pareto chart (a), main effects (b) and response surface plot (c) of the effect of sugarcane molasse (SM) and whey on pH in the ensiling of lemongrass (Cymbopogon citratus) leaves.
The model explained $87.3 \%$ of the variation found for $\mathrm{pH}$ in the silage. The $\mathrm{pH}$ of the silage varied from 5.7 to 4.6 in each treatment (Table 1). The $\mathrm{pH}$ decrease at the onset of the ensiling was presumably related to lactic acid production. The $\mathrm{pH}$ reduction could be due to the rapid degradation of the carbohydrates added with the SM (McKendrick et al., 2003). These carbohydrates were used immediately by lactic acid forming bacteria resulting in a reduced $\mathrm{pH}$ (Weinberg and Muck, 1996). The decrease in $\mathrm{pH}$ aided to hydrolyze the plant polysaccharides (Zhang et al., 2000). Whey increased the acidity and components, such as albumin and lacto globulin rich in sulfur amino acids (cysteine and methionine) and minerals (Ha and Zemel, 2003), generated better conditions for bacterial growth by increasing the fermentative lactic acid production (Zhang et al., 2000). Whey also contained lactic acid bacteria (LAB), such as Lactobacillus delbreueckii, L. helveticus and Streptomyces termophilus. Lactic acid will reduce $\mathrm{pH}$ inhibiting the growth of undesirable bacteria (Mannu et al., 2002).

The chemical characteristics of the silage derived from lemongrass leaves with addition of SM (15\%) and whey $(25 \%)$ are given in Table 2. The ash content was higher in lemongrass after silage than raw lemongrass leaves. This increase in ash content may be due to the SM and whey added. Shafaghat et al. (2010) reported $0.12 \mathrm{mg}$ $\mathrm{L}^{-1}$ ash content of SM, while for whey, Outinen et al. (2010) reported an average of $0.44 \mathrm{~g} 100 \mathrm{~g}^{-1}$. The main minerals in whey are $\mathrm{Na}, \mathrm{K}, \mathrm{Ca}, \mathrm{Mg}, \mathrm{Cl}$, and $\mathrm{P}$ (Outinen et al., 2010). These minerals probably favor the growth of LAB's. The neutral detergent fiber content was higher in lemongrass leaves before ensiling than at end of ensiling. On the contrary, $\mathrm{N}$ free extract was higher in lemongrass leaves further ensiling. The fiber content decreased as cellulolytic microorganisms degraded (hemi)cellulose (Lin et al., 1992).

The organic matter and total protein content and the ether extractable matter of the lemongrass leaves were not significantly affected by ensiling with $15 \%$ SM and $25 \%$ whey. This is important, as a key factor in ensiling

Table 2. Chemical composition before and after ensiling (15 d) of lemongrass leaves (Cymbopogon citratus) amended with sugarcane molasse $(15 \%)$ and whey $(25 \%)$.

\begin{tabular}{lccc}
\hline Characteristics & $\begin{array}{c}\text { Before } \\
\text { ensiling }\end{array}$ & $\begin{array}{c}\text { After } \\
\text { ensiling }\end{array}$ & $\begin{array}{c}\text { MSD }^{\mathrm{a}} \\
(0.05)\end{array}$ \\
\cline { 2 - 4 } Ash & $11.7(0.2) \mathrm{b}$ & $12.3(0.2) \mathrm{a}$ & 0.2 \\
Organic matter & $88.3(0.5) \mathrm{a}$ & $87.7(0.2) \mathrm{a}$ & 0.1 \\
Crude protein & $6.2(0.1) \mathrm{a}$ & $6.6(0.3) \mathrm{a}$ & 0.1 \\
Ether extract & $7.9(0.8) \mathrm{a}$ & $9.0(0.5) \mathrm{a}$ & 0.5 \\
Neutral detergent fiber & $29.7(0.4) \mathrm{a}$ & $24.6(0.31) \mathrm{b}$ & 1.2 \\
Nitrogen free extract & $44.5(0.4) \mathrm{b}$ & $47.5(0.86) \mathrm{a}$ & 1.5 \\
Silage quality & & & \\
Color & & Olive-green & \\
Taste & & Pleasant & \\
Structure & & Firm & \\
pH & & 4.1 & \\
\end{tabular}

${ }^{a}$ MSD: Minimum significant difference $(\mathrm{P}<0.05)$; values between parenthesis are standard deviations of the mean $(n=5)$; values within the row with a different letter denote significant differences between treatments $(\mathrm{P}<0.05)$. 
is to maintain the DM content while reducing effluent production (Haigh, 1999). A negative relationship has often been found between the DM content of the ensiled crop and the amount of effluent produced and silage effluent is a major source of agricultural pollution (Megías et al., 1999). Losses of nitrogenous compounds were negligible and indicative of a suitable fermentation, although changes in their distribution might have occurred during the ensilage (Driehuis and van Wikselaar, 2001).

\section{Silage quality}

The silage color was olive-green and similar to the color of the lemongrass leaves before ensiling. The taste of the ensiled lemongrass leaves was characterized as pleasant; the texture was firm, but not compact while the $\mathrm{pH}$ was 4.1 after $15 \mathrm{~d}$ (Table 2). These are characteristics of good quality silage. Omokanye et al. (2001) reported that a pleasant taste is common for well made silage and a good silage product usually preserves the original color of the raw plant material. The texture of the silage was as reported for good silage (Kung and Shaver, 2002). Generally, the $\mathrm{pH}$ is one of the simplest and quickest ways of evaluating silage quality (Babayemi, 2009). Silage of good quality should have a much lower $\mathrm{pH}$ than the original product (Meneses et al., 2007). Lemongrass silage was a $\mathrm{pH} 9.2$ at the beginning of the experiment and 4.1 after $5 \mathrm{~d}$ (Table 3 ).

\section{Comparison with a commercial product}

Changes in $\mathrm{pH}$ and lactic acid were registered in lemongrass silage supplemented with 15\% SM and $25 \%$ whey and were compared with lemongrass silage with commercial additive (Pro B\&W®). Addition of SM and whey resulted in a higher lactic acid production and a lower $\mathrm{pH}$ than the lemon leaves ensiled with the commercial product (Table 3). A rapid production of lactic acid is important to obtain high quality silage (Rong et al., 2010). Lactic acid is responsible for the inactivation of plant enzymes and undesirable microorganism that might inhibit fermentation or lead to silage deterioration even after the ensiling was over, i.e. silage with a low stability (Opitz von Boberfeld, 2001; Kondo et al., 2004).

Table 3. Changes in $\mathrm{pH}$ and lactic acid production in the silage of lemongrass leaves by-product (Cymbopogon citratus) with addition of sugarcane molasse (SM) and whey and commercial additive (Pro B\&W $\mathbf{W}^{\circledR}$ ).

\begin{tabular}{|c|c|c|c|c|c|}
\hline \multirow[b]{2}{*}{ Treatment } & \multicolumn{5}{|c|}{ Silage time } \\
\hline & $0 \mathrm{~d}$ & $3 \mathrm{~d}$ & $5 \mathrm{~d}$ & $7 \mathrm{~d}$ & $15 \mathrm{~d}$ \\
\hline & & & $\mathrm{pH}-$ & & \\
\hline SM + whey & $9.2 b$ & $5.2 b$ & $4.1 \mathrm{~b}$ & $4.1 b$ & $4.1 b$ \\
\hline Commercial & $10.0 \mathrm{a}$ & $6.8 \mathrm{a}$ & $6.2 \mathrm{a}$ & $6.1 \mathrm{a}$ & $5.4 \mathrm{a}$ \\
\hline \multirow[t]{2}{*}{$\operatorname{MSD}(\mathrm{P}<0.05)$} & 0.6 & 1.2 & 1.3 & 1.4 & 1.2 \\
\hline & & $-\mathrm{La}$ & id $(\mathrm{g} \mathrm{k}$ & M) & \\
\hline SM + whey & $0.09 \mathrm{a}$ & $1.5 \mathrm{a}$ & $2.4 \mathrm{a}$ & $2.6 \mathrm{a}$ & $2.8 \mathrm{a}$ \\
\hline Commercial & $0.09 \mathrm{a}$ & $0.3 b$ & $0.6 \mathrm{~b}$ & $0.9 \mathrm{~b}$ & $1.1 \mathrm{~b}$ \\
\hline $\operatorname{MSD}(\mathrm{P}<0.05)$ & 0.03 & 0.9 & 1.0 & 1.2 & 1.2 \\
\hline
\end{tabular}

Values are the mean of five replicates $(n=5)$; values within the column with a different letter denote significant differences between treatments $(\mathrm{P}<0.05)$; MSD: Minimum significant difference $(\mathrm{P}<0.05)$.

\section{CONCLUSIONS}

It was shown that lemongrass leaves can be effectively ensiled with whey and sugarcane molasse. A maximum $\mathrm{pH}$ decrease was found with $25 \%$ whey and $15 \%$ sugarcane molasses and lemongrass silage suitable for ruminants was obtained within $15 \mathrm{~d}$. The $\mathrm{pH}$ decrease at the onset of the ensiling was presumably related to lactic acid production. The silage was of good quality based on color, taste, structure and $\mathrm{pH}$. Further experiments will be required to determine whether similar results can be achieved in commercial silos.

\section{ACKNOWLEDGEMENTS}

This research was funded by Fomix project CHIS-0778825 .

Melaza de caña de azúcar y suero de leche como aditivos en el ensilaje de hojas de zacate de limón (Cymbopogon citratus [DC.] Stapf). Después de la extracción del aceite esencial de zacate limón (Cymbopogon citratus [DC.] Stapf) por destilación con vapor (tratamiento térmico) se obtiene un residuo. Este residuo podría ser utilizado para alimentación animal. El potencial de la melaza de caña y suero de leche como aditivos para ensilar hojas de zacate limón fue investigado. El material vegetal se obtuvo después que los aceites esenciales se extrajeron de las hojas de zacate limón usando destilación con vapor. Las hojas de zacate limón se picaron, mezclaron con melaza de caña y suero de leche y se colocaron en recipientes cilíndricos de plástico y se cerraron herméticamente. El diseño experimental para la optimización del $\mathrm{pH}$ fue uno de superficie de respuesta factorial $3^{2}$ con tres repeticiones. Se utilizó melaza de caña de azúcar 5, 10 y $15 \%$ (p/p) y suero de leche 20,25 y $30 \%$ (p/p). Las diferentes mezclas se caracterizaron químicamente y se colocaron en recipientes de plástico herméticamente cerrados. El pH del ensilaje se redujo significativamente en cada uno de los tratamientos, pero la disminución del pH fue más rápida cuando se añadió melaza de caña. La concentración de ácido láctico fue de 2,8 $\mathrm{g} \mathrm{kg}^{-1} \mathrm{MS}$ en el ensilaje adicionado con $15 \%$ de melaza más $25 \%$ de suero de leche. La concentración de ácido láctico fue mayor que en el ensilaje complementado con aditivos comerciales después de 15 d. En conclusión, se demostró que las hojas de zacate limón que se obtienen como desecho después de extraerles los aceites esenciales pueden ser efectivamente ensiladas con melaza de caña de azúcar y suero de leche como aditivos para inducir una producción más rápida de ácido láctico.

Palabras clave: calidad del ensilado, metodología de superficie de respuesta, $\mathrm{pH}$, ácido láctico. 


\section{LITERATURE CITED}

AOAC. 1980. Official methods of analysis. $14^{\text {th }}$ ed. Association of Official Analytical Chemists (AOAC), Washington, DC., USA.

Babayemi, O.J. 2009. Silage quality, dry matter intake and digestibility by West African dwarf sheep of Guinea grass (Panicum maximum cv. Ntchisi) harvested at 4 and 12 week regrowths. African Journal of Biotechnology 8:3983-3988.

Bautista-Trujillo, G.U., M. Cobos, L.M.C. Ventura-Canseco, T. Ayora-Talavera, M. Abud-Archila, M.A. Oliva-Llaven, et al. 2009. Effect of sugarcane molasses and whey on silage quality of maize. Asian Journal Crop Science 1:34-39.

Cao, Y., M. De-jing, L. Jian, and J. Jie. 2008. Statistical optimization of xylanase production by Aspergillus niger AN-13 under submerged fermentation using response surface methodology. African Journal of Biotechnology 7:631-638.

Daniels, L.B., M.J. Smith, O.T. Stallcup, and J.M. Rakes. 1983. Nutritive value of ensiled broiler litter for cattle. Animal Feed Science and Technology 8:19-24.

Davies, Z.S., R.J. Gilbert, R.J. Merry, D.B. Kell, M.K. Theodorou, and G.W. Griffith. 2000. Efficient improvement of silage additives by using genetic algorithms. Applied Environmental Microbiology 66:1435-1443.

De Lurdes, M., E. Dapkeviius, I. Batista, M.J.R. Nout, F.M. Rombouts, and J.H. Houben. 1998. Lipid and protein changes during the ensilage of blue whiting (Micromesistius poutassou Risso) by acid and biological methods. Food Chemistry 63:97102.

Driehuis, F., and P.G. Van Wikselaar. 2001. Determination of microbial protein in perennial ryegrass silage. Grass and Forage Science 56:75-83.

Goering, H.K., and P.J. Van Soest. 1970. Forage fiber analysis (apparatus, reagents, procedures and some applications). USDA Agricultural Handbook $N^{\circ}$ 379. p. 1-37. USDA, Washington D.C., USA.

Ha, E., and M.B. Zemel. 2003. Functional properties of whey, whey components, and essential amino acids: mechanisms underlying health benefits for active people (review). Journal of Nutrition Biochemistry 14:251-258.

Haigh, P.M. 1999. Effluent production from grass silage treated with additives and made in large-scale bunker silos. Grass and Forage Science 54:208-218.

Hetta, M., J.W. Cone, A.M. Gustavsson, and K. Martinsson. 2003. The effect of additives in silages of pure timothy and timothy mixed with red clover on chemical composition and in vitro rumen fermentation characteristics. Grass and Forage Science 58:249-257.

Kahi, A.K., and T.O. Rewe. 2008. Biotechnology in livestock production: Overview of possibilities for Africa. African Journal of Biotechnology 7:4984-4991.

Kaya, S., and M.E. Caliskan. 2010. Effects of molasses and ground wheat additions on the quality of groundnut, sweet potato, and Jerusalem artichoke tops silages. African Journal of Agricultural Research 5:829-833.

Kondo, M., N. Naoki, K. Kazumi, and H.O. Yolota. 2004. Enhanced lactic acid fermentation of silage by the addition of green tea waste. Journal of Science Food Agriculture 84:728-734.

Kung, L., and R. Shaver. 2002. Interpretation and use of silage fermentation analysis reports. Focus on Forage Vol. 3. $\mathrm{N}^{\circ} 13$. University of Wisconsin, Madison, Wisconsin, USA.

Lin, C., K.K. Bolsen, B.E. Brent, and D.Y.C. Fung. 1992. Epiphytic lactic acid bacteria succession during pre-ensiling and ensiling periods of alfalfa and maize. Journal of Applied Bacteriology 73:375-387.

Madrid, J., A. Martínez-Teruel, F. Hernández, and M.D. Megías. 1999. A comparative study on the determination of lactic acid in silage by colorimetric, high-performance liquid chromatography and enzymatic methods. Journal of Science Food Agriculture 79:1722-1726

Mannu, L., G. Riu, R. Comunian, M.C. Fozzi, and F. Scintu. 2002. A preliminary study of lactic acid bacteria in whey starter culture and industrial Pecorino Sardo ewe's milk cheese: PCRidentification and evolution during ripening. International Dairy Journal 12:17-26.

Martínez-Avalos, A.M.M., G.D. Mendoza, M.A. Cobos, S. González, C.M. García-Bojalil, and R. Bárcena. 1998. Nutritional evaluation of cattle manure silage with molasses for ruminants. Animal Feed Science and Technology 70:257-264.

McKendrick, E.J., D.J. Roberts, and N.W. Offer. 2003. The value of malt distillers's grains ensiled with molasses sugar beet pellets as a feed for dairy cows. Grass and Forage Science 58:287-294.

Megías, M.D., A. Martínez-Teruel, and M.R. Hérnandez. 1999. Potential environmental impact of effluents from the Artichoke (Cynara scolymus L.) byproduct ensiling process using additives. Journal of Agricultural and Food Chemistry 47:2455-2458.

Meneses, M., M.D. Megías, J. Madrid, A. Martínez-Teurel, F. Hernández, and J. Oliva. 2007. Evaluation of the phytosanitary, fermentative and nutritive characteristics of the silage made from crude artichoke (Cynara scolymus L.) by-product feeding for ruminants. Small Ruminant Research 70:292-296.

Omokanye, A.T., O.S. Onifade, P.E. Olorunju, A.M. Adamu, R.J. Tanko, and R.O. Balogun. 2001. The evaluation of dual purpose groundnut (Arachis hypogaea) varieties for fodder and seed production in Shika, Nigeria. Journal of Agriculture Science 136:75-79.

Opitz von Boberfeld, W. 2001. Effect of homofermentative lactic acid bacteria concentrates on the aerobic stability of grass silage. German Journal of Agronomy 5:7-14.

Outinen, M., P. Rantamaki, and A. Heino. 2010. Effect of milk pretreatment on the whey composition and whey powder functionality. Journal of Food Science 75:E1-10.

Rong, Y., H. Jian-Guo, H. Xian, L. Zhiqiang, and L. Yuzhu. 2010. Effects of different corn silage: Alfalfa silage ratios and full fat extruded soybeans on milk composition, conjugated linoleic acids content in milk fat and performance of dairy cows. African Journal of Biotechnology 9:5465-5464.

SAS Institute. 1989. Statistic guide for personal computers. Version 6.04. SAS Institute, Cary, North Carolina, USA.

Shafaghat, H., G.D. Najafpouri, P.S. Rezaei, and M. Sharifzadeh. 2010. Optimal growth of Saccharomyces cerevisiae (PTCC 24860) on pretreated molasses for the ethanol production: the application of the response surface methodology. Chemical Industry \& Chemical Engineering Quarterly 16:199-206.

Taylor, K.A.C.C. 1996. A simple colorimetric assay for muramic acid and lactic acid. Applied Biochemistry and Biotechnology $56: 49-58$.

Weinberg, Z.G., and R.E. Muck. 1996. New trends and opportunities in the development and use of inoculants for silage. FEMS Microbiology Review 19:53-68.

Zhang, J.G., O. Tanaka, R. Uegaki, Y. Cali, and R. Kobayashi. 2000. The effect of inoculation and additives on $\mathrm{D}(-)$ and $\mathrm{L}(+)$ lactic acid production and fermentation quality of guineagrass (Panicum maximum Jacq.) silage. Journal of Science Food Agriculture 80:2186-2189. 